\title{
Berberine protects against esophageal mucosal damage in reflux esophagitis by suppressing proinflammatory cytokines
}

\author{
BYUNG KIL CHOO ${ }^{1}$ and SEONG-SOO ROH ${ }^{2}$ \\ ${ }^{1}$ Department of Crop Agriculture and Life Science, Chonbuk National University, Jeonju 561-756; \\ ${ }^{2}$ Department of Herbology, College of Korean Medicine, Daegu Haany University, Gyeongsan 712-715, Republic of Korea
}

Received April 12, 2013; Accepted June 25, 2013

DOI: $10.3892 /$ etm.2013.1202

\begin{abstract}
This study was performed to investigate the effects of berberine $(\mathrm{BB})$ in a rat model of gastroesophageal reflux disease (GERD), induced by pylorus and forestomach ligation. We evaluated cytotoxicity and proinflammatory biomarkers (nitric oxide, interleukin (IL)-1 $\beta$ and prostaglandin E2) in RAW 264.7 cells in vitro and anti-inflammatory effects in vivo. A total of 54 Sprague Dawley rats were divided into six groups: intact control rats; reflux esophagitis (RE) control rats; RE rats treated with $20 \mathrm{mg} / \mathrm{kg}$ omeprazole and $\mathrm{RE}$ rats treated with $\mathrm{BB}$ at doses of 20, 40 and $60 \mathrm{mg} / \mathrm{kg}$, respectively. All rats were fasted. RE was induced by pylorus and forestomach ligation one hour subsequent to the oral treatment. Six hours subsequent to the surgery, the rats were sacrificed, blood was collected from the abdominal vein and the esophagus and stomach were dissected. The gastric volume and the $\mathrm{pH}$ of the gastric juice were evaluated, prior to the esophagus being cut longitudinally and an inner mucosal area being imaged, to analyze mucosal damage indices. Proinflammatory biomarkers in the serum, including tumor necrosis factor (TNF)- $\alpha$, IL-1 $\beta$, IL-6 and monocyte chemoattractant protein (MCP)-1 were analyzed using an enzyme-linked immunosorbent assay (ELISA) kit, while the mRNA expression of TNF- $\alpha$, IL-1 $\beta$, IL-6 and plasminogen activator inhibitor (PAI)-1 was analyzed using a quantitative polymerase chain reaction (qPCR). Esophagic tissue damage in the $\mathrm{BB}$ groups was dose-dependently decreased compared with that in the RE control group. This result was consistent with significant reductions in the levels of proinflammatory biomarkers in the serum and in the expression of proinflammatory mRNA, specifically, TNF- $\alpha$, IL- $1 \beta$, IL- 6 and PAI-1. The results suggest that the anti-inflammatory and protective effects of BB may attenuate the severity of $\mathrm{RE}$ and prevent esophageal mucosal damage, in addition to
\end{abstract}

Correspondence to: Professor Seong-Soo Roh, Department of Herbology, College of Korean Medicine, Daegu Haany University, Yougok-dong, Gyeongsan-si 712-715, Republic of Korea E-mail:ddede@dhu.ac.kr

Key words: berberine, anti-inflammatory activity, tumor necrosis factor- $\alpha$, interleukin-1, MCP-1, PAI-1, interleukin-6 validating the use of $\mathrm{BB}$ as a pharmacological treatment for esophageal reflux disease.

\section{Introduction}

Reflux esophagitis (RE) is an inflammation of the lower esophagus due to the regurgitation of gastric acid, characterized by a burning pain in the chest (so-called heartburn) and nausea following eating. RE is usually a result of a malfunction of the lower esophageal sphincter (1). In addition, it is associated with an increase in gastric acid secretion and a westernization of lifestyle and diet (i.e. a high-fat diet), as well as a low prevalence of Helicobacter pylori (H.pylori) infection.

$H$. pylori is generally accepted as the most important type of bacteria in gastrointestinal disease. However, certain studies have suggested that the increased prevalence of RE following $H$. pylori eradication may be due to the protective role of $H$. pylori infection in patients with RE (2-4).

In humans, prolonged gastroesophageal reflux, including acidic gastric fluid, leads to esophageal mucosal injury, such as bleeding, erythema, erosions and ulcers (5). Medication used to treat RE include antacids, acid blockers, gastric motility agents and surgery. Acid blockers, which comprise histamine type 2 (H2) antagonists and proton pump inhibitors (PPIs), are the most commonly used treatments for RE. H2 antagonists, such as ranitidine and cimetidine, reduce acid production in the stomach, and PPIs, such as omeprazole and esomeprazole, also arrest the production of stomach acid (6). Usually, PPIs are more effective than $\mathrm{H} 2$ antagonists $(7,8)$. However, in spite of the marked therapeutic effect, a number of patients have suffered from incidences of relapse and shown incomplete mucosal healing, continued symptoms and complications $(9,10)$. Even with an adequate administration of $\mathrm{H} 2$ antagonists and PPIs, 40-60\% of patients have suffered from stricture of the esophagus or cancer, instead of recovering from the RE (8).

Previous studies have revealed a number of serious and unusual side-effects resulting from the long-term use of PPIs, such as hypomagnesemia, bowel symptoms and small intestinal bacterial overgrowths $(11,12)$. As a consequence of this fact, there are, at present, safety concerns regarding the long-term use of PPIs, making it necessary to search for effective and safe alternatives (13). Our previous study was carried out to evaluate the potential therapeutic effect of Curculiginis Rhizoma in RE by the suppression of proinflammatory cyto- 
kines (14). The reduction of factors that are associated with inflammation is important in the alleviation of RE.

The present study was performed to evaluate the effect of berberine (BB) in an acute model of RE in rats. RE was induced in the rats by pylorus and forestomach ligation, a technique that is considered to create a valuable simple animal model to mimic human RE.

$\mathrm{BB}$, a major natural constituent of the Chinese herb Coptidis Rhizoma, has been shown to exert potent antitumor, anti-inflammatory, antidiarrhea and antidiabetic effects (14-16). $\mathrm{BB}$ has been demonstrated to suppress proinflammatory responses through AMP-activated protein kinase (AMPK) activation (17-19) and to inhibit inflammatory cytokines, such as tumor necrosis factor (TNF)- $\alpha$, interleukin (IL)-1 $\beta$ and IL-6, and inflammatory mediators, such as nitric oxide [NO; produced by inducible nitric oxide synthase (iNOS)] and prostaglandin E2 [PGE2; produced by cyclooxygenase (COX)-2] (20-25).

The anti-inflammatory effects of BB in a rat model of acute $\mathrm{RE}$ were investigated by the analysis of gastric secretions, a histological assay of esophageal tissue, an enzyme-linked immunosorbent assay (ELISA) and the analysis of gene expression by quantitative polymerase chain reaction (qPCR). In vitro effects in RAW 264.7 cells were also evaluated.

\section{Materials and methods}

Materials and animals. BB chloride was obtained from Waco Pure Chemical Industries, Ltd (cat. no. 022-05501, lot no. STL2430; Osaka, Japan) and was dissolved in distilled water. Omeprazole was purchased from Sigma-Aldrich (St. Louis, MO, USA) and dissolved in polyethylene glycol (Sigma-Aldrich) at a concentration of $0.1 \%$.

Five-week-old male Sprague-Dawley rats (Central Lab. Animal Inc., Seoul, Korea), weighing 160-180 g, were housed under normal laboratory conditions at $25 \pm 1^{\circ} \mathrm{C}$ with a controlled 12-h light-dark cycle and maintained on standard rodent chow and tap water. The experimental protocols were performed in accordance with the internationally accepted principles for the use and care of laboratory animals, as stated in the US guidelines (26). When necessary, the rats were deprived of food, although access to water was maintained, $18 \mathrm{~h}$ prior to the experiments. All animals were kept in raised mesh-bottom cages to prevent coprophagy. Nine rats were used in each group. The study was approved by the Institutional Review Board (number DHU2012-23).

Cell culture and chemical treatment. The RAW 264.7 cells were obtained from the American Tissue Culture Collection (Manassas, VA, USA) and were cultured in Dulbecco's modified Eagle's medium (DMEM) containing 10\% fetal bovine serum (FBS) in an atmosphere containing $5 \% \mathrm{CO}_{2}$. The cells were treated with BB diluted in DMEM with 5\% FBS for $24 \mathrm{~h}$, depending on the experimental designs.

Cell viability assay. The effect of $\mathrm{BB}$ on the viability of the cells was estimated using the Cell Counting kit (CCK)-8 (Dojindo Molecular Technologies, Inc., Rockville, MD, USA), in accordance with the manufacturer's instructions. Cells were seeded in a 96-well plate and then incubated with various concentrations $(10,20$ and $40 \mu \mathrm{M})$ of BB for $24 \mathrm{~h}$. Absorbance was measured with a microplate reader (Thermo Fisher Scientific Inc., Waltham, MA, USA) at $450 \mathrm{~nm}$.

NO production. RAW 264.7 cells $\left(2.5 \times 10^{4}\right.$ cells $/ \mathrm{ml}$ in a $96-w e l l$ plate) were treated with lipopolysaccharide (LPS; $1 \mu \mathrm{g} / \mathrm{ml}$ ) alone or with $\mathrm{BB}(10,20$ or $40 \mu \mathrm{M})$ for $24 \mathrm{~h}$. The culture supernatants were mixed with an equal volume of Griess reagent (Promega Corporation, Madison, WI, USA) and incubated at room temperature for $10 \mathrm{~min}$. Absorbance was measured at $540 \mathrm{~nm}$ with a microplate reader. Nitrite levels in the samples were determined by comparisons against a sodium nitrite curve.

PGE2 and IL-1 $\beta$ production. RAW 264.7 cells were seeded in a 96 -well plate at a density of $2.5 \times 10^{5}$ cells $/ \mathrm{ml}$ and then treated with LPS $(1 \mu \mathrm{g} / \mathrm{ml})$ alone or with $\mathrm{BB}(10,20$ or $40 \mu \mathrm{M})$ for $24 \mathrm{~h}$. The PGE2 concentration in the culture supernatants was quantified using a competitive enzyme immunoassay kit (R\&D Systems Inc., Minneapolis, MN, USA) in accordance with the manufacturer's instructions. IL-1 $\beta$ levels were determined using a commercially available ELISA kit (R\&D Systems Inc.), in accordance with the manufacturer's instructions. The ELISA was performed in 96-well polystyrene microplates with a specific monoclonal antibody coating. Absorbance was measured at $540 \mathrm{~nm}$ in a microplate reader.

Acute RE induction. All 54 rats were starved of food for $18 \mathrm{~h}$ prior to the RE induction surgery; however, free access to water was maintained. The rats were anesthetized with an intraperitoneal injection of $0.75 \mathrm{mg} / \mathrm{kg}$ Zoletil $^{\circledR}$ (Virbac S.A., Carros, France). A midline laparotomy was performed to expose the stomach, prior to the pylorus and the transitional junction between the forestomach and the corpus being exposed and subsequently ligated with 2-0 silk thread (only sham control rats were not ligated). The vagus nerves were left intact. Following surgery, the 54 rats were divided into six groups of nine rats each. In the intact control group and the RE control group, no further treatment was performed in addition to the previously mentioned surgical procedure. However, the rats in the omeprazole group were additionally treated with $20 \mathrm{mg} / \mathrm{kg}$ omeprazole $1 \mathrm{~h}$ prior to surgery and the rats in the BB groups were treated with 20,40 and $60 \mathrm{mg} / \mathrm{kg} \mathrm{BB}$, respectively, $1 \mathrm{~h}$ prior to abdominal surgery.

Analysis of gastric secretions. After sacrifice, each rat stomach was washed with $1 \mathrm{ml}$ phosphate-buffered saline (PBS) with a $1,000 \mu 1$ micropipette and the gastric contents were collected. In addition, the volume of gastric juice was examined. The $\mathrm{pH}$ of the collected gastric juice was measured using a $\mathrm{pH}$ meter (EcoMet; iSTEK Co., Seoul, South Korea).

Effect of BB on cytokine levels in the serum. In order to study the effect of $\mathrm{BB}$ on cytokine levels in the serum, immediately following the termination of the experiment, venous blood samples were drawn from the abdominal vein, placed into vials and used for the determination of plasma TNF- $\alpha$, IL-1 $\beta$, IL-6 and monocyte chemoattractant protein (MCP)-1 levels. Blood samples were collected and centrifuged at 1,800 $\mathrm{x} g$ for $15 \mathrm{~min}$ at a temperature of $15^{\circ} \mathrm{C}$, prior to the plasma being collected using a micropipette and stored at $-80^{\circ} \mathrm{C}$ until the ELISA was performed. 
Table I. Sequences of primers.

\begin{tabular}{lll}
\hline Gene & Primer direction & Sequence \\
\hline IL-1 $\beta$ & Forward & 5'-CAC CTC TCA AGC AGA GCA CAG-3' \\
TNF- $\alpha$ & Reverse & 5'-GGG TTC CAT GGT GAA GTC AAC-3' \\
& Forward & 5'-CCA GGA GAA AGT CAG CCT CCT-3' \\
IL-6 & Reverse & 5'-TCA TAC CAG GGC TTG AGC TCA-3' \\
& Forward & 5'-CGAAAGTCAACTCCATCTGCC-3' \\
PAI-1 & Reverse & 5'-GGCAACTGGCTGGAAGTCTCT-'3 \\
& Forward & 5'-CCGATGGGCTCGAGTATGA-3' \\
GAPDH & Reverse & 5'-TTGTCTGATGAGTTCAGCATCCA-3' \\
& Forward & 5'-ATGGCACAGTCAAGGCTGAGA-3' \\
& Reverse & 5'-CGCTCCTGGAAGATGGTGAT-3' \\
\hline
\end{tabular}

IL, interleukin; TNF, tumor necrosis factor, PAI, plasminogen activator inhibitor; GAPDH, glyceraldehyde 3-phosphate dehydrogenase.

The serum levels of the proinflammatory cytokines, TNF- $\alpha$, IL-1 $\beta$ and IL-6, and the chemokine, MCP-1, were evaluated with a Multi-Analyte ELISArray ${ }^{\circledR}$ kit (Millipore (Rockford, IL, USA), in accordance with the manufacturer's instructions. The color intensity of the reaction was estimated using a Luminex luminometer (Awareness Technology Inc., Palm City, FL, USA) at $490 \mathrm{~nm}$.

Effect of BB on TNF- $\alpha, I L-1 \beta, I L-6$ and plasminogen activator inhibitor (PAI)-1 mRNA transcript expression level by qPCR. Total RNA was extracted from the intestinal graft from the esophagus using TRIzol reagent (Invitrogen Life Technologies, Inc., Grand Island, NY, USA), in accordance with the manufacturer's instructions. RNA content was measured by 260/280 UV spectrophotometry. qPCR analysis, using a SYBR-Green PCR kit, was conducted using glyceraldehyde 3-phosphate dehydrogenase (GAPDH), IL-6, TNF- $\alpha$, IL-1 $\beta$ and PAI-1 primers (Table I), as described previously (1). The expression of all transcripts was normalized to GAPDH levels. qPCR analysis was conducted using an ABI PRISM ${ }^{\circledR} 7000$ Sequence Detection System (Applied Biosystems, Foster City, CA, USA), in accordance with the manufacturer's instructions. The thermal cycling conditions were: $10 \mathrm{~min}$ at $95^{\circ} \mathrm{C}$ to activate the Amplitaq Gold ${ }^{\circledR}$ DNA polymerase, followed by 40 cycles of $95^{\circ} \mathrm{C}$ for $15 \mathrm{sec}$ and $60^{\circ} \mathrm{C}$ for 1 min with the ABI PRISM ${ }^{\circledR} 7000$ Sequence Detection System (Applied Biosystems). Using the manufacturer's software, qPCR data were plotted as the fluorescence signal versus the cycle number. The cycle threshold was defined as the cycle number at which the fluorescence signal crossed the threshold.

The expression of each gene was normalized to GAPDH mRNA content and calculated relative to the control using the comparative cycle threshold method.

Determination of gross and microscopic esophageal mucosal damage. Rats were sacrificed and the entire esophagus was removed, prior to a lengthwise incision being made in the esophagus using scissors. Following this, the esophagus was gently rinsed with $0.9 \% \mathrm{NaCl}$ and an image was captured using a digital camera (Sony, Tokyo, Japan). Examination of gross mucosal injury was conducted using the i-Solution Lite soft- ware program (Innerview Co., Sungnam, South Korea) and a gross lesion index was applied as follows: 0, appeared as normal glistening mucosa; 1 , edematous mucosa with focal hemorrhage spots; 2, multiple erosions with hematins attached; 3, linear ulcerations with yellowish exudates and 4 , coalesced ulcerations. The gross esophageal mucosa protecting ratio was calculated as follows: Esophageal mucosa protecting ratio $(\%)=$ [total area of esophagus $\left(\mathrm{mm}^{2}\right)$-width of area with esophageal mucosal injury $\left.\left(\mathrm{mm}^{2}\right)\right] /$ width of total area of esophagus $\left(\mathrm{mm}^{2}\right) \times 100$.

For microscopic evaluation, the opened esophagus was cut to isolate the middle segment. This segment was embedded in paraffin, cut into $2-\mu \mathrm{m}$ sections and stained using hematoxylin and eosin (H\&E) for microscopic evaluation. The stained slices were subsequently observed under an optical microscope, analyzed using the i-Solution Lite software program (Innerview Co.) and assessed using the three-part histological activity index as follows: i) extent of esophageal ulcers: 0 , none; 1, erosion; 2, multiple erosions; 3 , ulceration and 4, large, excavated ulcer; ii) degree of inflammation: 0 , none; 1 , mild; 2 , moderate; 3 , severe and 4, absent; iii) damage to the mucosa: $0,0-10 \% ; 1,10-30 \% ; 2,30-60 \%$ and $3,60-100 \%$.

Statistical analysis. Results are expressed as the mean \pm standard deviation. Statistical analysis was performed using analysis of variance (ANOVA) and two-way ANOVA tests with a Tukey post hoc test where appropriate. Data are expressed as the mean \pm standard deviation of each group. A Student's t-test was also used for statistical analysis. $\mathrm{P}<0.05, \mathrm{P}<0.01$ and $\mathrm{P}<0.001$ were considered to indicate statistically significant differences.

\section{Results}

Cytotoxicity and anti-inflammatory activity of BB in vitro. To examine the effect of BB on cell growth in RAW 264.7 cell, the cells were treated with various concentrations (10, 20 and $40 \mu \mathrm{M}$ ) of BB for $24 \mathrm{~h}$. It was observed that BB did not affect normal cell growth (Fig. 1A). Thus, in the following experiments, the effects of BB at all concentrations were studied on cells with a normal growth status. Inflammatory leukocytes are stimulated by LPS, leading to the release of inflammatory mediators of NO 
and PGE2. In the evaluation of the anti-inflammatory effect of BB on RAW 264.7 cells, it was observed that BB inhibited the LPS-induced elevation of NO production; at concentrations of 10,20 and $40 \mu \mathrm{M}, \mathrm{BB}$ inhibited the production of NO by RAW 264.7 cells in a concentration-dependent manner. Furthermore, the amount of PGE2 released by the BB-treated cells was reduced in comparison with that by the LPS-treated control cells (Fig. 1C). The level of IL-1 $\beta$ production by the activated RAW 264.7 cells was significantly increased compared with that of the normal control cells $(\mathrm{P}<0.05)$; however, the IL-1 $\beta$ production of the cells treated with each concentration of BB was significantly reduced compared with that of the LPS-treated control group ( $\mathrm{P}<0.01$, Fig. 1D).

Effects on gross mucosal damage. In the normal intact group, no lesion damage or mucosal injury, such as hyperemia, multiple erosions with hematins attached, coalesced ulcerations or serosanginous exudates were observed (Fig. 2A). However, a severe longitudinal lesion with hyperemia, multiple erosions with hematins attached, coalesced ulcerations and serosanginous exudates were observed in the esophagi of the RE control group (Fig. 2B). The pathological area of the esophagi of the $\mathrm{RE}$ control group was grossly increased compared with that in the intact group. However, the positive control group treated with $20 \mathrm{mg} / \mathrm{kg}$ omeprazole had less damage than the RE control group (Fig. 2C). The gastric injury of each BB-treated group comprised only scattered erosions or mild hemorrhagic spots with whitish exudates scattered along the esophagus (Fig. 2D-F).

The gross injury index of the RE control was $46.4 \pm 3.9 \%$, whereas the index of the positive control treated with omeprazole was $0.5 \pm 0 \%$, and the indices of the groups treated with

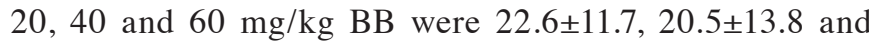
$16.9 \pm 12.6 \%$, respectively. Therefore, the gross injury indices of the BB groups were significantly dose-dependently decreased compared with that of the RE control (Fig. 2).

The macroscopic observations of the rats with RE with and without pretreatment with BB are shown in Fig. 3. Mucosal ulceration was markedly suppressed in the rats pretreated with BB (Fig. 3).

Effect on gastric volume and gastric juice $p H$. The gastric volume of the normal intact group was $1.03 \pm 0.04 \mathrm{ml}$ (containing $1 \mathrm{ml}$ PBS). However, the gastric volume of the RE control group was significantly increased compared with that of the intact group $(2.61 \pm 0.8 \mathrm{ml} ; \mathrm{P}<0.01)$. The gastric volumes of the positive control group treated with $20 \mathrm{mg} / \mathrm{kg}$ omeprazole $(2.6 \pm 0.8 \mathrm{ml})$ and the RE groups pretreated with 20, 40 and $60 \mathrm{mg} / \mathrm{kg} \mathrm{BB}(2.4 \pm 0.7,2.45 \pm 0.6$ and $2.3 \pm 0.8 \mathrm{ml}$, respectively) were not significantly different compared with that of the RE control group; however, they were significantly higher than that of the intact control group $(\mathrm{P}<0.01$ for all; Fig. 4).

The administration of omeprazole $(20 \mathrm{mg} / \mathrm{kg})$ significantly increased the gastric acid $\mathrm{pH}$ in the $\mathrm{RE}$ rats $(\mathrm{P}<0.01)$. However, the gastric acid $\mathrm{pH}$ values of the groups treated with $\mathrm{BB}$ were not significantly different from those of the RE group (Fig. 4).

Effects on serum TNF- $\alpha, I L-1 \beta, I L-6$ and MCP-1 levels. To examine the effects of $\mathrm{BB}$ on proinflammatory cytokines (TNF- $\alpha$, IL-1 $\beta$ and IL-6) and a chemokine (MCP-1) in surgi-
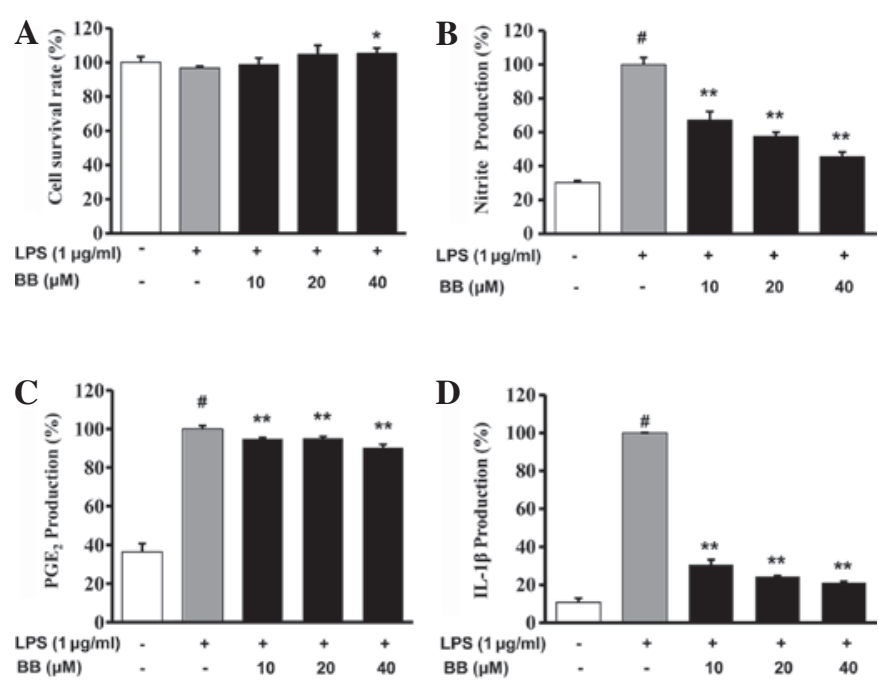

Figure 1. Effects of berberine (BB) on cell proliferation and the lipopolysaccharide (LPS)-induced release of nitric oxide (NO), prostaglandin E2 (PGE2) and interleukin (IL)-1 $\beta$ in RAW 264.7 cells. (A) A Cell Counting kit (CCK)-8 assay was used to evaluate the proliferation of RAW 264.7 cells treated for $24 \mathrm{~h}$ with LPS alone or with LPS and BB. (B) The effect of BB on LPS-induced NO production was estimated as described in Materials and methods. (C) PGE2 production was measured in RAW 264.7 cells treated for $24 \mathrm{~h}$ with LPS alone or with LPS and BB, using an enzyme immunoassay kit. (D) Release of IL-1 $\beta$ was also measured using an enzyme immunoassay kit. Each data point represents the mean \pm standard deviation of three independent experiments. ${ }^{\#} \mathrm{P}<0.05$ compared to control; ${ }^{*} \mathrm{P}<0.05 ;{ }^{* *} \mathrm{P}<0.01$ compared with LPS alone.

cally induced acute RE, cytokine levels in the serum were analyzed.

The serum level of TNF- $\alpha$ was $17.3 \pm 3.5 \mathrm{pg} / \mathrm{ml}$ in intact control rats. However, in the RE rats there was an increase in TNF- $\alpha$ production $(27.6 \pm 1.0 \mathrm{pg} / \mathrm{ml})$. Treatment of the RE rats with omeprazole $(21.9 \pm 3.3 \mathrm{pg} / \mathrm{ml}, \mathrm{P}<0.05), 40 \mathrm{mg} / \mathrm{kg} \mathrm{BB}$ $(20.9 \pm 1.4 \mathrm{pg} / \mathrm{ml}, \mathrm{P}<0.05)$ and $60 \mathrm{mg} / \mathrm{kg} \mathrm{BB}(18.9 \pm 1.6 \mathrm{pg} / \mathrm{ml}$, $\mathrm{P}<0.01)$ significantly inhibited this increase (Fig. 5A).

The serum IL-1 $\beta$ level was $52.1 \pm 6.4 \mathrm{pg} / \mathrm{ml}$ in the RE control rats, which was significantly higher than the levels in the rats treated with omeprazole $(31.3 \pm 8.2 \mathrm{pg} / \mathrm{ml}, \mathrm{P}<0.01), 40 \mathrm{mg} / \mathrm{kg}$ BB $(36.2 \pm 9.6 \mathrm{pg} / \mathrm{ml}, \mathrm{P}<0.05)$ and $60 \mathrm{mg} / \mathrm{kg} \mathrm{BB}(30 \pm 11 \mathrm{pg} / \mathrm{ml}$, $\mathrm{P}<0.001)$, indicating that these treatments significantly inhibited the increase in IL-1 $\beta$ level following RE induction (Fig. 5B).

The serum IL-6 level of the normal intact group was $178.7 \pm 11.5 \mathrm{pg} / \mathrm{ml}$. However, surgically inducing acute $\mathrm{RE}$ in the rats resulted in an increase in IL- 6 production $(1,243 \pm 89.5 \mathrm{pg} / \mathrm{ml}, \mathrm{P}<0.001)$ compared with the control group. Rats treated with $20 \mathrm{mg} / \mathrm{kg}$ omeprazole $(694.4 \pm 35.4 \mathrm{pg} / \mathrm{ml})$, $40 \mathrm{mg} / \mathrm{kg} \mathrm{BB}$ and $60 \mathrm{mg} / \mathrm{kg}$ BB demonstrated significantly lower serum IL-6 levels than the RE control group $(\mathrm{P}<0.01$, $\mathrm{P}<0.05$, and $\mathrm{P}<0.001$, respectively; Fig. 5C).

In the normal intact group, the MCP-1 level was 1052.2 $\pm 488 \mathrm{pg} / \mathrm{ml}$. However, RE induction in the rats resulted in an increase in the level of MCP-1 production $(2,583.5 \pm 71.8 \mathrm{pg} / \mathrm{ml})$. The rats treated with $20 \mathrm{mg} / \mathrm{kg}$ omeprazole $(2,066.7 \pm 232.1 \mathrm{pg} / \mathrm{ml}), 40 \mathrm{mg} / \mathrm{kg} \mathrm{BB}(1,950.4 \pm 175.4 \mathrm{pg} / \mathrm{ml})$ and $60 \mathrm{mg} / \mathrm{kg} \mathrm{BB}(1,669.4 \pm 150.1 \mathrm{pg} / \mathrm{ml})$ had significantly decreased MCP-1 levels compared with those of the RE control group $(\mathrm{P}<0.05$ for omeprazole and $40 \mathrm{mg} / \mathrm{kg} \mathrm{BB}$ and $\mathrm{P}<0.01$ for $60 \mathrm{mg} / \mathrm{kg} \mathrm{BB}$, Fig. 5D). 

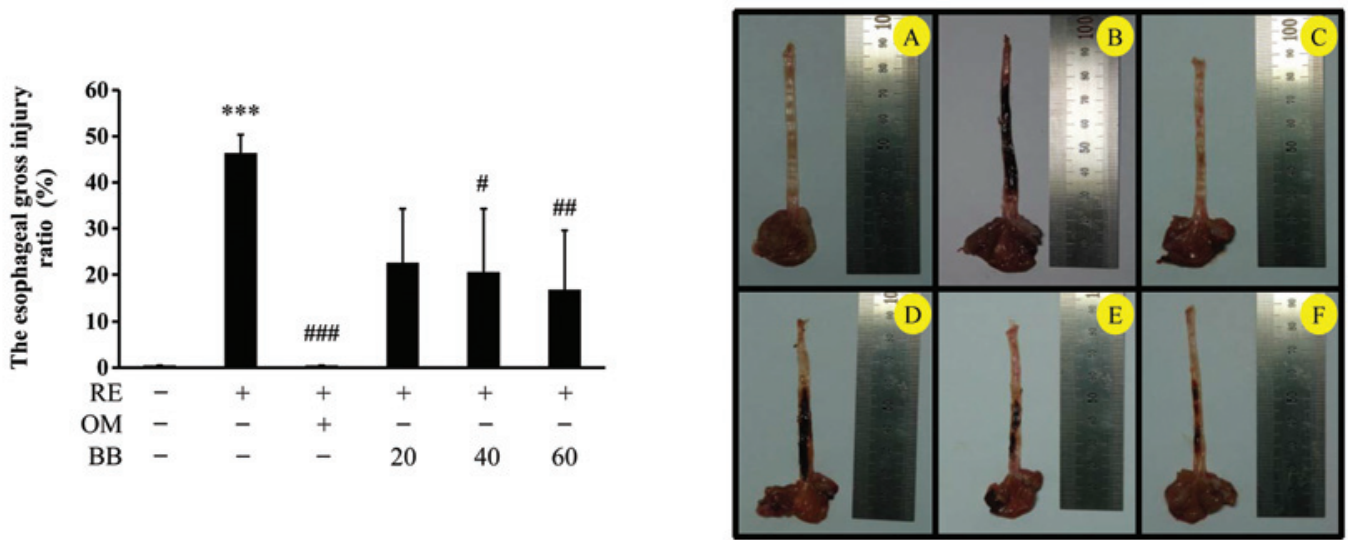

Figure 2. Effects of berberine (BB) on gross esophageal damage in rats with reflux esophagitis (RE). The rat esophagus was removed immediately subsequent to sacrifice and cut in the longitudinal direction from the gastroesophageal junction to the pharynx. The inner mucous was washed away with phosphate-buffered saline (PBS). The dissected esophagus was laid out on paper and photographic images captured with an optical digital camera, and the damage was analyzed using the i-Solution Lite software program (Innerview Co., Sungnam, South Korea). (A) Normal intact rat esophagus; (B) esophagus from rat with surgically induced acute RE treated with distilled water; (C) esophagus with induced acute RE treated with $20 \mathrm{mg} / \mathrm{kg}$ omeprazole (OM); (D-F) esophagi with induced acute RE treated with (D) 20, (E) 40 and (F) $60 \mathrm{mg} / \mathrm{kg}$ BB. Values are expressed as the mean \pm standard deviation. ${ }^{* * *} \mathrm{P}<0.001$ compared with the intact rat group; ${ }^{\#} \mathrm{P}<0.05$ and ${ }^{\# /} \mathrm{P}<0.01$ compared with the RE control rat group. $\mathrm{RE}$, control rat with pylorus and forestomach ligation treated with distilled water. OM, positive control rat with pylorus and forestomach ligation treated with omeprazole $(20 \mathrm{mg} / \mathrm{kg})$. BB, rat with pylorus and forestomach ligation treated with BB (20, 40 and $60 \mathrm{mg} / \mathrm{kg}$, respectively).
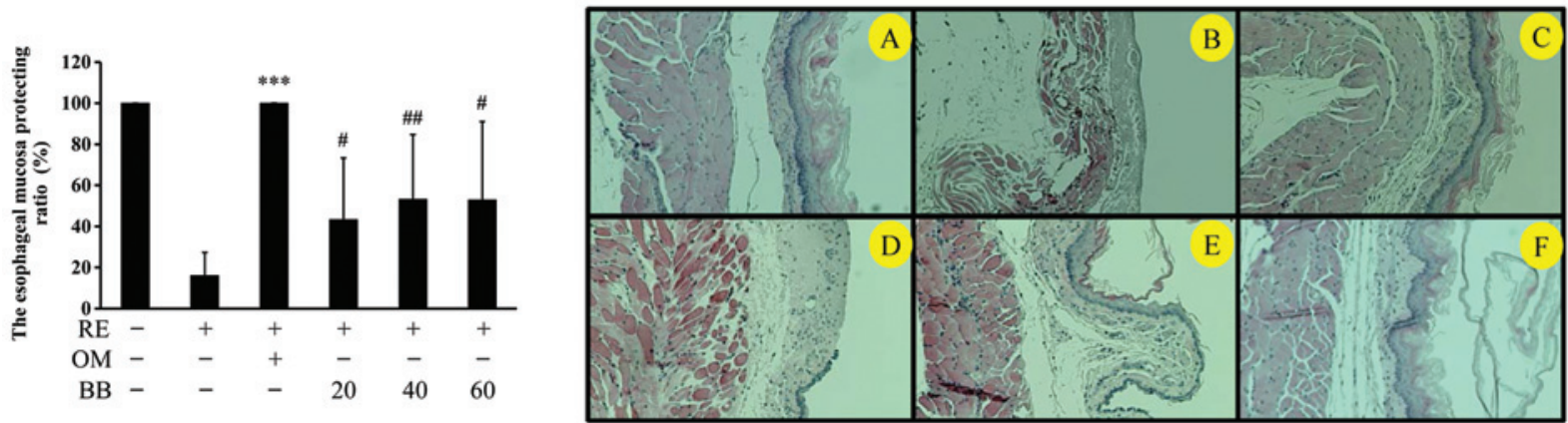

Figure 3. Effect of berberine (BB) on the histology of the esophageal mucosa. The rat esophagus was removed immediately subsequent to sacrifice and cut in the longitudinal direction from the gastroesophageal junction to the pharynx. The middle portion of the esophagus was collected and sections of the esophagus were stained with hematoxylin and eosin. Images were captured using an optical digital camera and analyzed with the i-Solution Lite software program (Innerview Co., Sungnam, South Korea). (A) Normal intact rat; (B) control rat with reflux esophagitis (RE) induced by pylorus and forestomach ligation treated with distilled water; (C) positive control rat with pylorus and forestomach ligation treated with omeprazole (OM; $20 \mathrm{mg} / \mathrm{kg})$; (D-F) rat with pylorus and forestomach ligation treated with (D) 20, (E) 40 and (F) $60 \mathrm{mg} / \mathrm{kg}$ BB. Magnification, $\mathrm{x} 100{ }^{* * * *} \mathrm{P}<0.001$ compared with the intact rat group; ${ }^{*} \mathrm{P}<0.05$ and ${ }^{\# \#} \mathrm{P}<0.01$ compared with the RE control rat group.

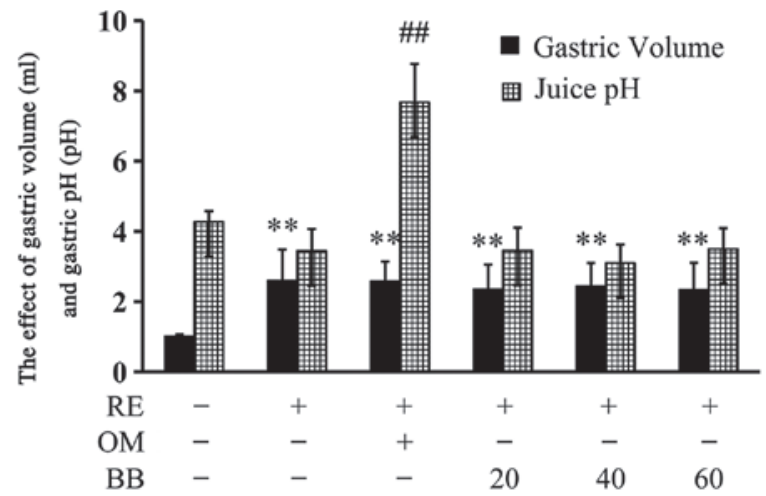

Figure 4. Effect of berberine (BB) on gastric volume and gastric juice $\mathrm{pH}$ in rats with reflux esophagitis (RE). The rat stomach was removed immediately subsequent to sacrifice and washed with phosphate-buffered saline (PBS) to collect the gastric contents. The gastric contents were centrifuged at $1,800 \mathrm{x} g$ for $5 \mathrm{~min}$ and their volumes were measured. The $\mathrm{pH}$ of the collected gastric juice was also measured using a pH meter. Values are expressed as the mean \pm standard deviation of nine rats. ${ }^{* *} \mathrm{P}<0.01$ compared with normal, intact rats. ${ }^{\# \#} \mathrm{P}<0.01$ compared with RE rats. RE, rat with pylorus and forestomach ligation, treated with distilled water; OM, rat with pylorus and forestomach ligation, treated with omeprazole $(20 \mathrm{mg} / \mathrm{kg})$. BB, rat with pylorus and forestomach ligation, treated with $\mathrm{BB}(20,40$ or $60 \mathrm{mg} / \mathrm{kg})$. 
Table II. Histological activity index in esophageal tissue assessed by hematoxylin and eosin staining.

$$
\text { Score }
$$

\begin{tabular}{lccc}
\hline Group & Extent of esophageal ulcers & Degree of inflammation & Damage to mucosa \\
\hline Intact & 0 & 0 & 0 \\
Reflux esophagitis & $3.33 \pm 0.71^{\mathrm{a}}$ & $2.78 \pm 0.67^{\mathrm{a}}$ & $3^{\mathrm{a}}$ \\
Omeprazole & $0.11 \pm 0.33^{\mathrm{d}}$ & $0^{\mathrm{d}}$ & $0^{\mathrm{d}}$ \\
Berberine $20 \mathrm{mg} / \mathrm{kg}$ & $2.83 \pm 0.75$ & $2.33 \pm 0.51$ & $2.16 \pm 1.1$ \\
Berberine $40 \mathrm{mg} / \mathrm{kg}$ & $2.50 \pm 0.54^{\mathrm{c}}$ & $1.33 \pm 0.81^{\mathrm{b}}$ & $2.00 \pm 1.3^{\mathrm{b}}$ \\
Berberine $60 \mathrm{mg} / \mathrm{kg}$ & $1.70 \pm 0.51^{\mathrm{d}}$ & $1.00 \pm 0.63^{\mathrm{d}}$ & $1.10 \pm 1.0^{\mathrm{c}}$ \\
\hline
\end{tabular}

Data are presented as the mean \pm standard deviation. ${ }^{\mathrm{a}} \mathrm{P}<0.001$ compared with the intact group; ${ }^{\mathrm{b}} \mathrm{P}<0.05,{ }^{\mathrm{c}} \mathrm{P}<0.01,{ }^{\mathrm{d}} \mathrm{P}<0.001$ compared with control rats with induced reflux esophagitis. The omeprazole group had induced reflux esophagitis and were treated with $20 \mathrm{mg} / \mathrm{kg}$ omeprazole; the berberine groups had induced reflux esophagitis and were treated with 20,40 and $60 \mathrm{mg} / \mathrm{kg}$ berberine, respectively.
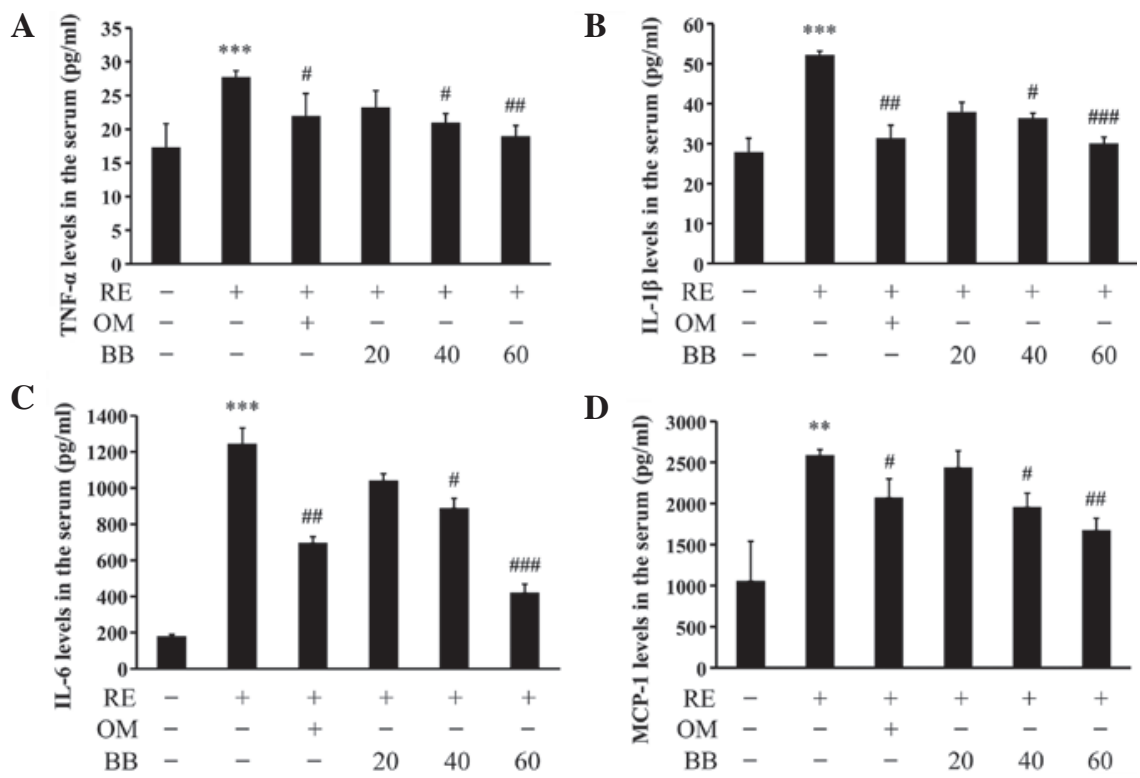

Figure 5. Effect of berberine (BB) on serum levels of tumor necrosis factor (TNF)- $\alpha$, interleukin (IL)-1 $\beta$, IL-6 and monocyte chemoattractant protein (MCP)-1. Whole blood was collected from the abdominal vein with a $5 \mathrm{ml}$ syringe, at the time of sacrifice. Collected blood was centrifuged at 1,800 x g for $15 \mathrm{~min}$ to collect the serum. Serum levels of the proinflammatory biomarkers (A) TNF- $\alpha$, (B) IL-1 $\beta$, (C) IL-6 and (D) MCP-1 were evaluated with the Multi-Analyte ELISArray ${ }^{\circledR}$ Kit (Millipore, Rockford, IL, USA) in accordance with the manufacturer's instructions. Color intensity of the reaction was estimated using the Luminex luminometer(Awareness Technology Inc., Palm City, FL, USA) at $490 \mathrm{~nm}$. Values are expressed as the mean \pm standard deviation. ${ }^{* * *} \mathrm{P}<0.001$ compared with the intact rat group; ${ }^{~} \mathrm{P}<0.05,{ }^{\# \#} \mathrm{P}<0.01$ and ${ }^{\# \# \#} \mathrm{P}<0.001$ compared with the reflux esophagitis (RE) control rat group. RE, control rat with pylorus and forestomach ligation treated with distilled water; OM, positive control rat with pylorus and forestomach ligation treated with omeprazole (20 mg/kg). BB, rat with pylorus and forestomach ligation treated with $\mathrm{BB}(20,40$ and $60 \mathrm{mg} / \mathrm{kg}$, respectively).

Effects on TNF- $\alpha, I L-1 \beta, I L-6$ and PAI-1 mRNA expression, analyzed using $q P C R$. As shown in Fig. 6, the expression levels of TNF- $\alpha$, IL-1 $\beta$, IL-6 and PAI-1 mRNA were low in the intact esophageal mucosa. However, mRNA expression levels in the RE control were significantly increased, due to the inflammatory reaction in the esophagus. The expression levels of TNF- $\alpha$, IL-1 $\beta$, IL- 6 and PAI-1 mRNA in the rats pretreated with a concentration of $60 \mathrm{mg} / \mathrm{kg}$ BB were significantly decreased compared with those of the RE control group ( $\mathrm{P}<0.05$, Fig. 6).

Histological analysis of esophageal mисоsa. Esophageal tissue stained with $\mathrm{H} \& \mathrm{E}$ revealed no microscopic mucosal changes in the intact rat (Fig. 3A). The normal esophagus exhibited a thin epithelial layer with squamous cells and inflammatory cells were not observed in the submucosal layers. By contrast, $6 \mathrm{~h}$ subsequent to the induction of RE, the RE group rats developed large coalesced longitudinal ulcers in the lower and middle sections of the esophagus. Mucosal damage and hyperemia of the epithelial layers and edema and hemorrhage in the mucosa and submucosa were observed in the RE control animals (Fig. 3B). Furthermore, the mucosal layers were damaged by gastric acid. By contrast, esophageal damage, edema, neutrophil infiltration and gastric hemorrhage were not observed in the rats treated with omeprazole (Fig. 3C) and the RE rats treated with 40 and $60 \mathrm{mg} / \mathrm{kg}$ BB (Fig. 3E and F, respectively) also showed less severe pathological changes.

The histological activity indices were significantly reduced in the rats pretreated with omeprazole and BB (Table II). 
A
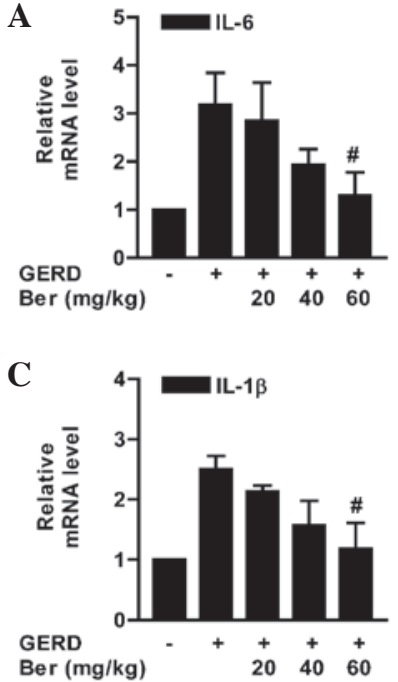

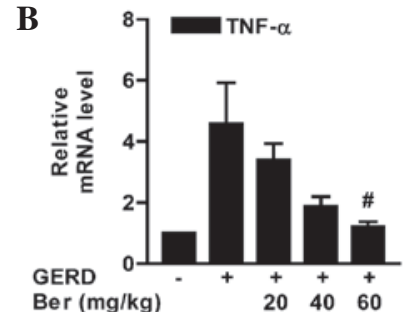

D

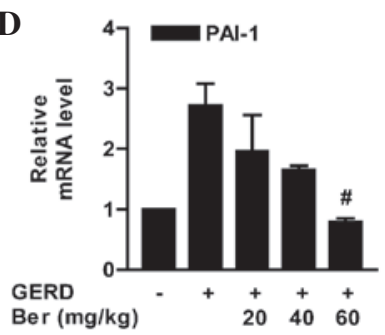

Figure 6. Effect of berberine (Ber) on tumor necrosis factor (TNF)- $\alpha$, interleukin IL-1 $\beta$, IL-6 and plasminogen activator inhibitor (PAI)-1 mRNA expression in the esophagus. The rat esophagus was removed immediately subsequent to sacrifice and cut in the longitudinal direction from the gastroesophageal junction to the pharynx. Expression of (A) TNF- $\alpha$, (B) IL-1 $\beta$, (C) IL-6 and (D) PAI-1 mRNA was quantified by quantitative polymerase chain reaction (qPCR) in intact animals, reflux esophagitis (RE) control rats and $\mathrm{RE}$ rats pretreated orally with 20,40 or $60 \mathrm{mg} / \mathrm{kg}$ berberine. RE was induced by pylorus and forestomach ligation. RE control rats were treated with distilled water. Values are expressed as the mean \pm standard deviation. ${ }^{\#} \mathrm{P}<0.001$ compared with the RE control rat group. GERD, gastroesophageal reflux disease.

\section{Discussion}

The present study demonstrated that the administration of BB significantly inhibited gastric acid-induced esophageal damage. A number of herbal therapies have been proposed for the treatment of RE; however, the efficacy of BB as a treatment for RE has not, to the best of our knowledge, been investigated.

The pathogenesis of RE is associated with oxidative stress, inflammation and apoptosis. A number of studies have demonstrated the suppressive effect of BB on inflammation (27-29). The proinflammatory cytokines, TNF- $\alpha$, IL-1 $\beta$ and IL-6, are important in the response to microbial infection or tissue damage. BB treatment has been reported to significantly downregulate the expression of proinflammatory genes, such as TNF- $\alpha$, IL-1 $\beta$, IL- 6 and MCP-1 (30).

In the present study, we investigated whether BB inhibited the inflammation associated with RE. The suppressive effects of $\mathrm{BB}$ on the production of inflammatory mediators in LPS-stimulated RAW 264.7 cells and rat serum were observed.

Two of the major cytokines are TNF- $\alpha$ and IL-1. TNF- $\alpha$ induces a number of physiological effects, including septic shock, inflammation and cytotoxicity. TNF- $\alpha$ is also known as cachectin, due to the fact that it mediates fever and cachexia, and is responsible for the numerous detrimental effects associated with bacterial sepsis, rheumatoid arthritis and Crohn's disease. TNF- $\alpha$ is released by monocytes and macrophages in response to various stimuli including bacterial LPS, which is a principal mediator of the deleterious effects of endotoxin (31). IL-1 is an inflammatory cytokine that is released in response to infection or cell injury by cells of the innate immune system, such as macrophages. Keratinocytes store and release
IL-1 following wounding of the skin, rapidly signaling to the surrounding cells that the external barrier has been damaged. IL-1 $\beta$ is important for the initiation and enhancement of the inflammatory response $(32,33)$.

IL-6 is produced in various cells, such as fibroblasts, monocytes, T cells, B cells, microglia, endothelial cells, neurons and astrocytes (34). IL-6, originally identified as a B cell differentiation factor, and synthesized in response to IL-1 $\beta$, has a critical role in the host reaction to inflammation, inducing the synthesis of acute inflammatory proteins (35). IL-1 $\beta$ and IL-6 are involved in the acute response phase of the immune response (36). IL-6 is a key regulator of cell growth, survival and differentiation, and, as such, is involved in a variety of biological responses, including the immune response, inflammation, hematopoiesis and oncogenesis.

MCP-1 is a member of the C-C chemokine family, and possesses inflammatory properties (37). MCP-1 is important in the recruitment and activation of leukocytes during acute inflammation (38). MCP-1 upregulation is associated with macrophage recruitment, angiogenesis and survival in human breast cancer.

Elizabeth et al (39) demonstrated that PGE2 regulated the production of PAI-1 in primary cultures of rat calvarial osteoblasts. PAI-1 production is increased by TNF- $\alpha$ (40) and IL-1 (41). It has been revealed that the induction and transcriptional regulation of the PAI-1 gene may be mediated by cytokines and inflammatory mediators, such as endotoxins, IL-1, transforming grow th factor (TGF)- $\beta$, insulin, TNF- $\alpha$, hepatocyte growth factor (HGF) and phorbol 12-myristate 13 -acetate (42).

$\mathrm{BB}$ is known to inhibit inflammatory cytokines, such as TNF- $\alpha$, IL- $1 \beta$ and IL-6, and inflammatory mediators, such as NO (produced by iNOS) and PGE2 (produced by COX-2) (20-25,27-29). In the present study, the gastric volume and the $\mathrm{pH}$ of the gastric juice in the $\mathrm{RE}$ rats were not significantly altered following treatment with BB, so the BB-treated rats were stimulated by gastric acid to the same extent as the RE control rats. However, the gross esophageal lesions and histological indications of mucosal damage in the BB-treated rats were significantly reduced compared with those in the control RE rats, with regard to the extent of esophageal ulcers, the degree of inflammation, the damage to the mucosa and the survival ratio of the mucosal layer.

In conclusion, the present results indicate that $\mathrm{BB}$ suppresses inflammation of the esophagus. In support of our hypothesis, NO, PGE2 and IL-1 $\beta$ production levels were significantly diminished in vitro in RAW 264.7 cells that had been stimulated with LPS. Furthermore, serum levels of the inflammatory biomarkers, TNF- $\alpha$, IL-1 $\beta$, IL-6 and MCP-1, were significantly reduced in vivo in rats treated with $\mathrm{BB}$, compared with the levels in untreated RE rats. TNF- $\alpha$, IL-1 $\beta$, IL-6 and PAI-1 mRNA expression levels in esophageal tissue was also significantly reduced compared with the levels in the untreated RE control rats.

\section{Acknowledgements}

This study was supported by the National Research Foundation of Korea (NRF) and grant funded by the Korea government(MSIP; No. 2012-0009400). 


\section{References}

1. Mahattanadul S, Ridtitid W, Nima S, Phdoongsombut N, Ratanasuwon P and Kasiwong S: Effects of Morinda citrifolia aqueous fruit extract and its biomarker scopoletin on reflux esophagitis and gastric ulcer in rats. J Ethnopharmacol 134: 243-250, 2011.

2. Fujiwara Y, Higuchi K, Hamaguchi M, Takashima T, Watanabe T, Tominaga K, Oshitani N, Matsumoto $\mathrm{T}$ and Arakawa T: Increased expression of transforming growth factor-alpha and epidermalgrowthfactor receptors in rat chronic reflux esophagitis. J Gastroenterol Hepatol 19: 521-517, 2004.

3. Yoshida N: Inflammation and oxidative stress in gastroesophageal reflux disease. J Clin Biochem Nutr 40: 13-23, 2007.

4. Labenz J, Blum AL, Bayendörffer E, Meining A, Stolte M and Börsch G: Curing Helicobacter pylori infection in patients with duodenal ulcer disease may provoke reflux esophagitis. Gastroenterology 112: 1442-1447, 1997.

5. Varanasi RV, Fantry GT and Wilson KT: Decreased prevalence of Helicobacter pylori infection in gastroesophageal reflux disease. Helicobacter 3: 188-194, 1998.

6. Haruma K, Hamada H, Mihara M, Kamada T, Yoshihara M, Sumii K, Kajiyama G and Kawanishi M: Negative associated between Helicobacter pylori infection and reflux esophagitis in older patients: case-control study in Japan. Helicobacter 5: 24-29, 2000.

7. Shin JM and Kim N: Pharmacokinetics and pharmacodynamics of the proton pump inhibitors. J Neurogastroenterol Motil 19: 25-35, 2013.

8. Carling L, Axelsson CK, Forssell H, Stubberöd A, Kraglund K, Bonnevie O and Ekström P: Lansoprazole and omeprazole in the prevention of relapse of reflux oesophagitis: a long-term comparative study. Aliment Pharmacol Ther 12: 985-990, 1998.

9. Youssef SS, Iskandar SB, Scruggs J and Roy TM: Acute pancreatitis associated with omeprazole. Int J Clin Pharmacol Ther 43: 558-561, 2005.

10. Katz PO: Optimizing medical therapy for gastroesophageal reflux disease: state of the art. Rev Gastroenterol Disord 3: 59-69, 2003.

11. Lahiri S, Singh P, Singh S, Rasheed N, Palit G and Pant KK: Melatonin protects against experimental reflux esophagitis. J Pineal Res 46: 207-213, 2009.

12. Colin-Jones DG: Histamine-2-receptor antagonists in gastrooesophageal reflux. Gut 30: 1305-1308, 1989.

13. Doornebal J, Bijlsma R and Brouwer RM: An unknown but potentially serious side effect of proton pump inhibitors: hypomagnesaemia. Ned Tijdschr Geneeskd 153: A711, 2009 (In Dutch).

14. Ku SK, Kim JS, Seo YB, et al: Effect of Curculigo orchioides on reflux esophagitis by suppressing proinflammatory cytokines. Am J Chin Med 40: 1241-1255, 2012.

15. Compare D, Pica L, Rocco A, De Giorgi F, Cuomo R, Sarnelli G, Romano $\mathrm{M}$ and Nardone G: Effects of long-term PPI treatment on producing bowel symptoms and SIBO. Eur J Clin Invest 41: 380-386, 2011

16. Allescher HD and Wagner H: STW 5/Iberogast: multi-target-action for treatment of functional dyspepsia and irritable bowel syndrome. Wien Med Wochenschr 157: 301-307, 2007 (In German)

17. Wang XH, Jiang SM and Sun QW: Effects of berberine on human rheumatoid arthritis fibroblast-like synoviocytes. Exp Biol Med (Maywood) 236: 859-866, 2011.

18. Lou T, Zhang Z, Xi Z, Liu K, Li L, Liu B and Huang F: Berberine inhibits inflammatory response and ameliorates insulin resistance in hepatocytes. Inflammation 34: 659-667, 2011.

19. Kuo CL, Chi CW and Liu TY: The anti-inflammatory potential of berberine in vitro and in vivo. Cancer Lett 203: 127-137, 2004.

20. Jeong HW, Hsu KC, Lee JW, Ham M, Huh JY, Shin HJ, Kim WS and Kim JB: Berberine suppresses proinflammatory responses through AMPK activation in macrophages. Am J Physiol Endocrinol Metab 296: E955-E964, 2009.

21. Lu DY, Tang CH, Chen YH and Wei IH: Berberine suppresses neuroinflammatory responses through AMP-activated protein kinase activation in BV-2 microglia. J Cell Biochem 110: 697-705, 2010.

22. Wang Q, Zhang M, Liang B, Shirwany N, Zhu Y and Zou MH: Activation of AMP-activated protein kinase is required for berberine-induced reduction of atherosclerosis in mice: the role of uncoupling protein 2. PLoS One 6: e25436, 2011.
23. Shang W, Liu J, Yu X and Zhao J: Effects of berberine on serum levels of inflammatory factors and inflammatory signaling pathway in obese mice induced by high fat diet. Zhongguo Zhong Yao Za Zhi 35: 1474-1477, 2010 (In Chinese).

24. Shen YB, Piao XS, Kim SW, Wang L and Liu P: The effects of berberine on the magnitude of the acute inflammatory response induced by Escherichia coli lipopolysaccharide in broiler chickens. Poult Sci 89: 13-19, 2010.

25. Singh P, Singh N and Palit G: Analysing the role of COX-2 in acute oesophagitis and in melatonin-exerted protection against experimental reflux oesophagitis in rats. J Pharm Pharmacol 63: 1572-1580, 2011.

26. US Environmental Protection Agency. Health Effects Test Guidelines OPPTS 870.100. Washington, US EPA, 2012.

27. McAdam E, Haboubi HN, Forrester G, Eltahir Z, Spencer-Harty S, Davies C, Griffiths AP, Baxter JN and Jenkins GJ: Inducible nitric oxide synthase (iNOS) and nitric oxide (NO) are important mediators of reflux-induced cell signalling in esophageal cells. Carcinogenesis 33: 2035-2043, 2012.

28. Lee CH, Chen JC, Hsiang CY, Wu SL, Wu HC and Ho TY: Berberine suppresses inflammatory agents-induced interleukin-1beta and tumor necrosis factor-alpha productions via the inhibition of IkappaB degradation in human lung cells. Pharmacol Res 56: 193-201, 2007.

29. Choi BH, Ahn IS, Kim YH, Park JW, Lee SY, Hyun CK and Do MS: Berberine reduces the expression of adipogenic enzymes and inflammatory molecules of 3T3-L1 adipocyte. Exp Mol Med 38: 599-605, 2006

30. Xiao HB, Sun ZL, Zhang HB and Zhang DS: Berberine inhibits dyslipidemia in C57BL/6 mice with lipopolysaccharide induced inflammation. Pharmacol Rep 64: 889-895, 2012.

31. Jia L, Liu J, Song Z, Pan X, Chen L, Cui X and Wang M: Berberine suppresses amyloid-beta-induced inflammatory response in microglia by inhibiting nuclear factor-kappaB and mitogen-activated protein kinase signalling pathways. J Pharm Pharmacol 64: 1510-1521, 2012.

32. Yan F, Wang L, Shi Y, et al: Berberine promotes recovery of colitis and inhibits inflammatory responses in colonic macrophages and epithelial cells in DSS-treated mice. Am J Physiol Gastrointest Liver Physiol 302: G504-G514, 2012.

33. Jeong HW, Hsu KC, Lee JW, Ham M, Huh JY, Shin HJ, Kim WS and Kim JB: Berberine suppresses proinflammatory responses through AMPK activation in macrophages. Am J Physiol Endocrinol Metab 296: E955-E964, 2009.

34. Yoon HD, Jeong EJ, Choi JW, Lee MS, Park MA, Yoon NY, Kim YK, Cho DM, Kim JI and Kim HR: Anti-inflammatory effects of ethanolic extracts from Codium fragile on LPS-stimulated RAW 264.7 macrophages via nuclear factor kappaB inactivation. Fish Aquat Sci 14: 267-274, 2011.

35. Rodríguez-Hernández H, Simental-Mendía LE, Rodríguez-Ramírez G and Reyes-Romero MA: Obesity and inflammation: epidemiology, risk factors, and markers of inflammation. Int J Endocrinol 2013: 678159, 2013.

36. Rieder F, Biancani P, Harnett K, Yerian L and Falk GW: Inflammatory mediators in gastroesophageal reflux disease: impact on esophageal motility, fibrosis, and carcinogenesis. Am J Physiol Gastrointest Liver Physiol 298: G571-G581, 2010.

37. Gruol DL and Nelson TE: Physiological and pathological roles of interleukin-6 in the central nervous system. Mol Neurobiol 15: 3307-3339, 1997.

38. Heinrich PC, Castell JV and Andus T: Interleukin-6 and acute phase response. Biochem J 265: 621-636, 1990.

39. Allan EH and Martin TJ : Prostaglandin E2 regulates production of plasminogen activator isoenzymes, urokinase receptor, and plasminogen activator inhibitor-1 in primary cultures of rat calvarial osteoblasts. J Cell Physiol 165: 521-529, 1995.

40. Ortiz-Muñoz G, Martin-Ventura JL, Hernandez-Vargas P, et al: Suppressors of cytokine signaling modulate JAK/STAT-mediated cell responses during atherosclerosis. Arterioscler Thromb Vasc Biol 29: 525-531, 2009.

41. Wu AC, Morrison NA, Kelly WL and Forwood MR: MCP-1 expression is specifically regulated during activation of skeletal repair and remodeling. Calcif Tissue Int 92: 566-575, 2013.

42. Dawson SJ, Wiman B, Hamsten A, Green F, Humphries S and Henney AM: The two allele sequences of a common polymorphism in the promoter of the plasminogen activator inhibitor-1 (PAI-1) gene respond differently to interleukin-1 in HepG2 cells. J Biol Chem 268: 10739-10745, 1993. 